\title{
Knowledge and practices of pregnant women about folic acid in pregnancy in Abu Dhabi, United Arab Emirates
}

H. Al-Hossani, ${ }^{1}$ H. Abouzeid, ${ }^{7}$ M.M. Salah, ${ }^{7}$ H.M. Farag ${ }^{1}$ and E. Fawzy ${ }^{1}$

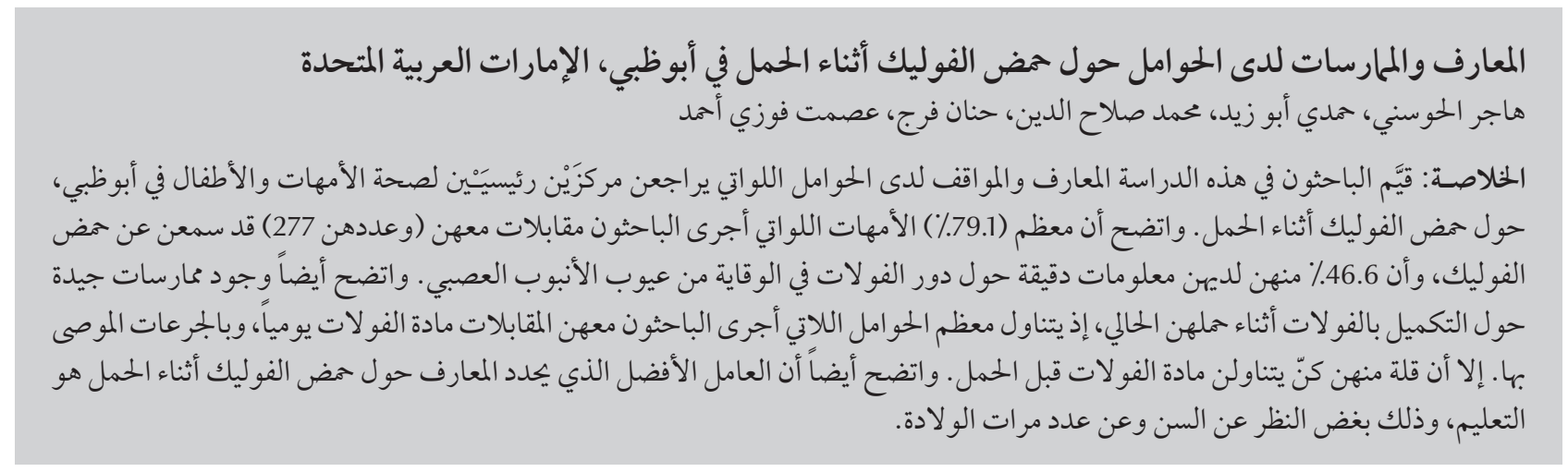

ABSTRACT This study assessed the knowledge and practices about folic acid in pregnancy among pregnant women attending 2 main maternal and child health centres in Abu Dhabi. The majority of the 277 interviewed mothers (79.1\%) had heard of folic acid and $46.6 \%$ had accurate knowledge about the role of folate in preventing neural tube defects. There were good practices regarding folate supplementation in the current pregnancy; most of the interviewed mothers took it daily and in the recommended dose. However, only a minority took it prior to pregnancy. Education, irrespective of age or parity, was the major factor determining better knowledge of folic acid in pregnancy.

Connaissances et pratiques des femmes enceintes en matière d'acide folique au cours de la grossesse à $\mathrm{Abu}$ Dhabi (Émirats arabes unis)

RÉSUMÉ La présente étude évalue les connaissances sur l'acide folique au cours de la grossesse et les pratiques en la matière chez des femmes enceintes fréquentant deux des principaux centres de soins maternels et infantiles d’Abu Dhabi. La majorité des 277 mères interrogées $(79,1 \%)$ avaient entendu parler de l'acide folique et 46,6 \% avaient des connaissances précises sur le rôle des folates dans la prévention des malformations du tube neural. De bonnes pratiques ont été observées en matière de supplémentation en folates au cours de la grossesse. La plupart des femmes interrogées prenaient quotidiennement la dose recommandée. Cependant, seule une minorité en avait pris avant la grossesse. L'éducation, indépendamment de l'âge ou de la parité, était le principal facteur déterminant de meilleures connaissances sur l'acide folique pendant la grossesse. 


\section{Introduction}

Neural tube defects (NTDs), including anencephaly, encephalocele and spina bifida, are common causes of morbidity and mortality among infants and neonates. The incidence of NTDs has declined substantially over the past 60 years and is about $1-2$ per 1000 babies in the general population [1].

The National Congenital Anomalies Registry is a population-based registry covering all births in the United Arab Emirates (UAE) and was launched in all medical districts in January 1999. The prevalence of NTDs in Abu Dhabi Emirate (the capital of UAE) is 0.94 per 1000 total births, which is comparable to other studies done in Abu Dhabi medical district which showed an incidence of 0.99 per 1000 total births [2,3].

Folate deficiency is one of the most common vitamin deficiencies in women. Women who consume a low level of folate during pregnancy are at risk for poor pregnancy outcomes, including NTDs [4]. While other factors have also been implicated [5], pre-conception folic acid supplementation prevents approximately $70 \%$ of NTDs. Although most women carrying an affected fetus do not have deficient blood folate levels, the risk of having an NTD-affected child is inversely correlated with red cell folate levels in pregnancy [6]. The most effective approach to combat this problem is daily supplementation with folic acid prior to pregnancy.

The aim of this study was to assess the knowledge and behaviour of a group of pregnant women about the role of folic acid in pregnancy in Abu Dhabi Emirate. The findings will help inform health education campaigns aimed at raising the awareness of women about the role of folic acid in pregnancy, particularly through premarital counselling programmes.

\section{Methods}

\section{Sample}

A representative sample of pregnant women of UAE nationality in Abu Dhabi Emirate were included in the study. The sample size was estimated using Epi-info 2000, version 1.11. Estimation of the total sample size was based on the size of the target population, the expected frequency (40\%), the worst acceptable sample size and a 95\% confidence level. Based on the previous data, the computed sample size was 351 .

The women were selected using a simple random technique. Pregnant women were recruited from 2 main maternal and child health $(\mathrm{MCH})$ centres that were commonly attended by UAE nationality residents for antenatal care. The centres were visited by the interviewers 3 times a week over a 2 -month period until the required sample size had been reached. Of the sample of women approached, 277 agreed to participate in the study.

\section{Data collection}

The specially designed questionnaires were administered by trained nurses and specialized nutritionists who interviewed the mothers at their respective $\mathrm{MCH}$ centres during antenatal visits. The questionnaire was divided into 4 parts: demographic and clinical data (mother's age, education and parity) and knowledge and behaviour of pregnant women concerning folic acid supplementation during pregnancy.

Knowledge was assessed as follows. The mother was asked about the role of folic acid in pregnancy and the answer was coded as: "correct or partially accurate" if she mentioned the importance of folic acid in preventing spina bifida, neural tube defects, birth defects or bone formation, and coded as "vague or incorrect" if she cited folic acid important for a healthy pregnancy, baby strength, tonic, etc. The mother was also questioned about her knowledge concerning foods rich in folate and this was classified as "accurate/partially accurate" if the interviewed mother mentioned green vegetables, and/or cereals and/or fruits, and as "vague or incorrect" if she mentioned healthy foods, better diet, etc.

Mothers were asked if they had they had altered their diet in any way during the current pregnancy. A mother was considered to have increased or probably increased her folate intake if she mentioned that the alteration in diet included an increase in green vegetables and/or cereals and/or fruit. Mothers were also asked if they had taken folic acid supplements during pregnancy and if so, the timing of the supplements (before pregnancy, during 1st month, after 1st month), the frequency (daily, interrupted) and whether this was in the recommended $(0.4 \mathrm{mg})$ dose.

\section{Analaysis}

Statistical analysis was carried out using SPSS, version 12. Confidence intervals (CI) quoted are given at the 95\% level of confidence. Simple logistic regression analysis was done using age, parity, education as the independent variables and knowledge of the mother about the effect of folic acid on pregnancy as the dependant variable.

\section{Results}

\section{Background characteristics}

A total of 277 pregnant women of UAE nationality agreed to participate in the study. The largest proportion of women interviewed were 20-29 years old (64.6\%); only 3 women (1.1\%) were $40+$ years (Table 1 ).

Compulsory education was considered as education until 12 years of age: $3.6 \%$ had received only compulsory education (Table 1) and $55.6 \%$ of the 


\begin{tabular}{|c|c|c|}
\hline \multicolumn{3}{|c|}{$\begin{array}{l}\text { Table } 1 \text { Age, level of education } \\
\text { and parity of the pregnant women } \\
\text { interviewed }(n=277)\end{array}$} \\
\hline Variable & No. & $\%$ \\
\hline \multicolumn{3}{|l|}{ Age (years) } \\
\hline$<20$ & 16 & 5.7 \\
\hline $20-24$ & 84 & 30.3 \\
\hline $25-29$ & 95 & 34.3 \\
\hline $30-34$ & 60 & 21.7 \\
\hline $35-39$ & 19 & 6.9 \\
\hline $40+$ & 3 & 1.1 \\
\hline \multicolumn{3}{|l|}{ Education } \\
\hline Compulsory & 10 & 3.6 \\
\hline $\begin{array}{l}\text { Preparatory/ } \\
\text { secondary }\end{array}$ & 113 & 40.8 \\
\hline University+ & 154 & 55.6 \\
\hline \multicolumn{3}{|l|}{ Parity } \\
\hline 1 & 89 & 32.1 \\
\hline 2 & 66 & 23.8 \\
\hline 3 & 44 & 15.9 \\
\hline 4 & 44 & 15.9 \\
\hline $5+$ & 34 & 12.3 \\
\hline
\end{tabular}

interviewed mothers had completed university education and more.

Nearly one-third $(32.1 \%)$ of the interviewed women were primigravidas and $12.3 \%$ were parity $5+$ (Table 1$)$.

\section{Knowledge of folic acid}

Of 277 mothers interviewed 219 (79.1\%) claimed to have heard of folic acid and 146 of those (66.7\%) reported that they knew about its importance in pregnancy (Table 2). These mothers were questioned about the role of folate in pregnancy, foods rich in folate and the proper time of supplementation. Of 146 of women who knew the importance of folic acid in pregnancy, $46.6 \%$ had accurate/partially accurate knowledge, $36.3 \%$ knew foods rich in folate and of these $28.3 \%$ had accurate knowledge. Regarding the proper time of folate supplementation in pregnancy, out of the 146 of pregnant women who knew its importance in pregnancy, 29.5\% mentioned before the last menstrual period and 34.9\% during the 1st month of pregnancy. Almost 10\% did not know the proper timing.
Out of the 219 mothers who had heard of folate, $60.7 \%$ said that doctors were the most common source of information, the next was knowledge from previous pregnancies (10.5\%) (Table 2). Nutritionists were the least common source of women's knowledge, mentioned by only $1.8 \%$

Overall $69.7 \%$ of the 277 pregnant women interviewed reported taking folate in the current pregnancy (Table 3). Most (65.3\%) took it after the 1st month of pregnancy, only a minority $(7.8 \%)$ took it before pregnancy. However, the great proportion of those women consumed it on daily basis (78.2\%) and in the recommended (0.4 $\mathrm{mg})$ dose (76.7\%).

\begin{tabular}{|c|c|c|}
\hline Variable & No. & $\%$ \\
\hline \multicolumn{3}{|l|}{ Awareness offolic acid } \\
\hline Heard of folic acid & 219 & 79.1 \\
\hline Never heard of folic acid & 58 & 20.9 \\
\hline \multicolumn{3}{|l|}{ Folic acid importance in pregnancy } \\
\hline Knew its importance & 146 & 66.7 \\
\hline Did not know & 73 & 33.3 \\
\hline Accurate/partially accurate knowledge & 68 & 46.6 \\
\hline Vague/incorrect knowledge & 78 & 53.4 \\
\hline \multicolumn{3}{|l|}{ Foods containing folic acid $(n=146)$} \\
\hline Knew foods containing folic acid & 53 & 36.3 \\
\hline Did not know & 93 & 63.7 \\
\hline Correct answer & 15 & 28.3 \\
\hline Vague/incorrect answer & 38 & 71.7 \\
\hline \multicolumn{3}{|c|}{ Proper time offolate supplementation in pregnancy $(n=146)$} \\
\hline Before last period & 43 & 29.5 \\
\hline During 1st month of pregnancy & 51 & 34.9 \\
\hline During 2nd month of pregnancy & 22 & 15.1 \\
\hline During 3rd month of pregnancy & 16 & 10.9 \\
\hline Don't know & 14 & 9.6 \\
\hline \multicolumn{3}{|l|}{ Source of knowledge $(n=219)$} \\
\hline Doctor & 133 & 60.7 \\
\hline Nutritionist & 4 & 1.8 \\
\hline Nurse & 9 & 4.1 \\
\hline Books and magazines & 12 & 5.5 \\
\hline Previous experience & 23 & 10.5 \\
\hline Mass media & 9 & 4.1 \\
\hline Friends and relatives & 16 & 7.3 \\
\hline Other & 13 & 6.0 \\
\hline
\end{tabular}

When pregnant women were asked whether they had altered their diet during pregnancy, $64.6 \%$ claimed that they did (Table 4). The proportion of women who were judged to have achieved an increased folate intake when they altered their diet was $23.8 \%$.

Pregnantwomen'sknowledgeabout folate supplementation was analysed by age, education and parity (Table 5). Accurate and/or partially accurate knowledge of the importance of folic acid in pregnancy was low among mothers $<20$ years compared with mothers in other age groups; it was highest in primagravidas and in mothers with higher education levels (Table 5). 


\begin{tabular}{|c|c|c|}
\hline Variable & No. & $\%$ \\
\hline \multicolumn{3}{|l|}{ Folate use in pregnancy } \\
\hline Did not take folate & 84 & 30.3 \\
\hline Took folate & 193 & 69.7 \\
\hline \multicolumn{3}{|c|}{ Time of supplementation $(n=193)$} \\
\hline Before pregnancy & 15 & 7.8 \\
\hline During 1st month & 52 & 26.9 \\
\hline After 1st month & 126 & 65.3 \\
\hline \multicolumn{3}{|c|}{ Way of supplementation $(n=193)$} \\
\hline Daily & 151 & 78.2 \\
\hline Interrupted & 42 & 21.8 \\
\hline \multicolumn{3}{|l|}{ Dosage $(n=193)$} \\
\hline Recommended (0.4 mg) & 148 & 76.7 \\
\hline Not as recommended & 45 & 23.3 \\
\hline
\end{tabular}

Appropriate alterations in diet were analysed by age, education and parity (Table 4). The proportion who reported altering their diet appropriately was greater among mothers aged 35-40 and 40+ years groups, while it was lower among mothers with only compulsory of education. No effect of parity was observed.

\section{Regression analysis}

Using multiple logistic regression analysis, the results show that education, irrespective of age or parity, was the major factor determining better knowledge of folic acid in pregnancy $(P<0.001)$ (Table 6).

\begin{tabular}{|c|c|c|c|c|}
\hline \multirow[t]{2}{*}{ Variable } & \multicolumn{4}{|c|}{ Pregnant women (\%) } \\
\hline & $\begin{array}{l}\text { Diet altered with } \\
\text { likely increase in } \\
\text { folate }\end{array}$ & $\begin{array}{l}\text { Diet altered with } \\
\text { no increase in } \\
\text { folate }\end{array}$ & $\begin{array}{l}\text { Diet not } \\
\text { altered }\end{array}$ & Total \\
\hline \multicolumn{5}{|l|}{ Age (years) } \\
\hline$<20$ & 12.4 & 31.3 & 56.3 & 100.0 \\
\hline $20-24$ & 25.0 & 36.9 & 38.1 & 100.0 \\
\hline $25-29$ & 26.3 & 43.2 & 30.5 & 100.0 \\
\hline $30-34$ & 18.3 & 50.0 & 31.7 & 100.0 \\
\hline $46-40$ & 31.6 & 26.3 & 42.1 & 100.0 \\
\hline$\geq 40$ & 33.3 & 33.3 & 33.3 & 100.0 \\
\hline \multicolumn{5}{|l|}{ Parity } \\
\hline 1 & 25.8 & 43.8 & 30.1 & 100.0 \\
\hline 2 & 19.7 & 42.8 & 37.9 & 100.0 \\
\hline 3 & 27.3 & 43.2 & 29.5 & 100.0 \\
\hline 4 & 20.5 & 31.8 & 47.7 & 100.0 \\
\hline $5+$ & 26.5 & 38.2 & 35.3 & 100.0 \\
\hline \multicolumn{5}{|l|}{ Education level } \\
\hline Compulsory & 9.1 & 27.3 & 63.6 & 100.0 \\
\hline $\begin{array}{l}\text { Preparatory/ } \\
\text { secondary }\end{array}$ & 26.5 & 31.9 & 41.6 & 100.0 \\
\hline University+ & 22.7 & 42.7 & 28.6 & 100.0 \\
\hline Total (No.) & $23.8(66)$ & 40.8 (113) & $35.4(98)$ & 100.0 \\
\hline
\end{tabular}

\section{Discussion}

It is well established that folic acid supplementation during pregnancy is associated with a significantly lower risk of having a child with NTDs, 2 independent clinical trials in 2002/03 showed that supplementing a woman's diet with folic acid before and during early pregnancy reduced the prevalence of NTDs by more than $70 \%[7,8]$.

Overall, $79.1 \%$ of the interviewed pregnant women in our study had heard about folic acid, and of these $66.7 \%$ were aware of the connection between folic acid and neural tube defects. Otherstudies have also investigated knowledge and practices among women in the reproductive age group. In Norway, Vollset and Lande reported that 50.4\% of women in the reproductive age group had heard about folate and about onethird knew about its role in pregnancy [9]. In the United States, only 13\% of all women surveyed knew that folic acid helps prevent birth defects [10]. Agnieszka et al. in Poland reported that $67.5 \%$ of women in the reproductive age group had heard or read about folate and $36.1 \%$ of them were aware of the connection between folate and NTDs [11].

Our findings showed that among those who knew that folate intake is important during pregnancy, $46.6 \%$ reported accurate/partially accurate knowledge. Also, around one-third of women who cited properly the role of folate in pregnancy knew foods rich in folate and $28.3 \%$ of them mentioned the proper foods. In Poland, $42.2 \%$ of women could identify foods rich in folate [11]. Similarly $29.5 \%$ of the women in the study reported that the proper time for folate supplementation should be before pregnancy. In Norway $0.4 \%$ of the studied population mentioned that the initial period for folate supplementation to prevent NTDs is before or early in pregnancy [7], while in the United States $7 \%$ of interviewed women knew 


\begin{tabular}{|c|c|c|c|c|}
\hline $\begin{array}{l}\text { Table } 5 \text { Pregnan } \\
\text { age, parity and }\end{array}$ & $\begin{array}{l}\text { women's knowledg } \\
\text { lucation }(n=277)\end{array}$ & bout folate & plementation a & ording to \\
\hline Variable & Pregnant w & nen with kı & ledge of folic aci & \\
\hline & $\begin{array}{c}\text { Accurate/ } \\
\text { partially accurate }\end{array}$ & $\begin{array}{l}\text { Vague/ } \\
\text { incorrect }\end{array}$ & No knowledge & Total \\
\hline Age (years) & & & & \\
\hline$<20$ & 25.0 & 75.0 & 0.0 & 100.0 \\
\hline $20-24$ & 48.6 & 46.6 & 2.8 & 100.0 \\
\hline $25-29$ & 50.0 & 48.1 & 1.9 & 100.0 \\
\hline $30-34$ & 36.1 & 61.1 & 2.8 & 100.0 \\
\hline $46-40$ & 50.0 & 50.0 & 0.0 & 100.0 \\
\hline$\geq 40$ & 50.0 & 50.0 & 0.0 & 100.0 \\
\hline Parity & & & & \\
\hline 1 & 55.3 & 44.7 & 0.0 & 100.0 \\
\hline 2 & 34.3 & 65.7 & 0.0 & 100.0 \\
\hline 3 & 48.0 & 48.0 & 4.0 & 100.0 \\
\hline 4 & 45.8 & 50.0 & 4.0 & 100.0 \\
\hline $5+$ & 33.3 & 58.3 & 8.3 & 100.0 \\
\hline Education level & & & & \\
\hline Compulsory & 33.7 & 63.9 & 2.4 & 100.0 \\
\hline $\begin{array}{l}\text { Preparatory/ } \\
\text { secondary }\end{array}$ & 37.5 & 57.5 & 5.0 & 100.0 \\
\hline University+ & 48.5 & 50.0 & 1.5 & 100.0 \\
\hline
\end{tabular}

that it should be taken before pregnancy to prevent birth defects [8].

Doctors played an important role in increasing women's awareness about the role of folate in pregnancy as mentioned by $60.7 \%$ of the pregnant women participating in this study, while the role of nutritionists was not encouraging. Previous experience was the second commonest source of knowledge. Agnieszka et al. reported that magazines and newspapers were the most commonly cited source of knowledge in their study followed by leaflets and general practitioners [11].

Although a programme to increase dietary folate intake of potential mothers may be effective in reducing NTDs, the only proven and practical preventive measure currently available is to take oral multivitamin supplements containing folic acid. Multivitamin supplementation has also been associated with the reduced incidence of other congenital malformations [12].

Concerning the behaviour of women regarding folate supplementation in the current pregnancy, the study revealed good practice, as most of them (69.7\%) took folate, and the majority of them took it on daily basis and in the recommended dose. Unfortunately, few of the interviewed women $(7.8 \%)$ had taken supplements before pregnancy: the development of defects in the neural tube occurs within the 1st month of pregnancy, often before the mother knows she is pregnant. In Malta 15\% of women who had just given birth to a baby took folic acid supplementation prior to pregnancy and $73 \%$ of them took it after the 1st month; $64 \%$ were taking $5000 \mu \mathrm{g}$ or more daily [13]. Agnieszka et al. reported that $14.2 \%$ of women in their study used a vitamin containing $0.4 \mathrm{mg}$ folate on a daily basis and $9.8 \%$ took it 4 weeks before pregnancy [11].

The present study showed that a majority of the interviewed women (64.6\%) had altered their diet in the current pregnancy but only a minority did so with an increase or probable increase in folate. In Malta $51 \%$ of women altered their diet during pregnancy and $34 \%$ of them had actually increased or probably increased folate intake [13].

As expected, education and mother's age were the most important factors indicated to improve mother's knowledge of folic acid and consequent compliance in taking it prior to pregnancy with appropriate alteration of diet. Accurate knowledge regarding the importance of folate in pregnancy and alteration of diet with probably increased folate diet were reported more by educated mothers and mothers 35 years and more. On the other hand, primigravidas reported accurate knowledge regarding the importance of folate in pregnancy more than mothers of other gravidity. Similar findings were reported in Malta [13].

Simple logistic regression showed that education was the most important significant factor influencing pregnant women's knowledge regarding the importance of folic acid in pregnancy.

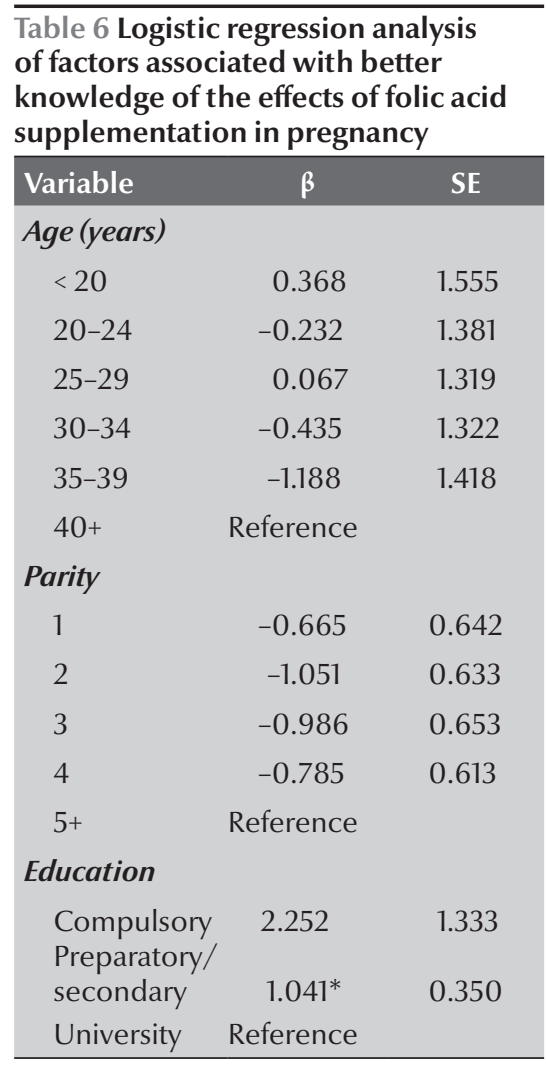

${ }^{*} P<0.05$.

$S E=$ standard error 


\section{Conclusion}

This study reflects the knowledge and behaviour of agroup of pregnantwomen regarding the role of folate in pregnancy and does not reflect the knowledge of all pregnant women or women in childbearing age in UAE.

The findings of the study are encouraging regarding the supplementation of folate in pregnancy, where more than three-quarters of mothers who took it in pregnancy did so in the recommended dose and on a daily basis, but most of them took it after the 1st month of pregnancy.

The results of the survey suggest that professional education is needed for health care providers to increase the awareness of pregnant women about the importance of folate supplementation in pregnancy.

Further studies are needed to identify effective approaches of increasing folic acid consumption and to evaluate approaches used. Food fortification may be the only population strategy of benefit in the effort to eliminate NTDs.

\section{Acknowledgments}

We are grateful to the members of the team who participated in the successful implementation of the study, especially Ms Fatima, Ms Salma and Ms Reema who interviewed the mothers in the vicinity of their health centres.

\section{References}

1. Laurence KM. The genetics and prevention of neural tube defects and 'uncomplicated' hydrocephalus. In: Emery AEH, Rimoin DL, eds. Principals and practice of medical genetics, 2nd ed. New York, Churchill Livingstone, 1990:323.

2. Al Hosani $\mathrm{H}$ et al. The National Congenital Abnormalities Registry (NCAR) in the United Arab Emirates. Eastern Mediterranean health journal, 2005, 11(4):690-99.

3. Al-Jawad ST et al. A survey of serious congenital morphological abnormalities in Abu Dhabi. Annals of tropical paediatrics, 1988, 8:76-9.

4. Berg MJ. The importance of folic acid. Journal of gender-specific medicine, 1999, 2(3):24-8.

5. González MJ et al. Folate supplementation and neural tube defects: a review of a public health issue. Puerto Rico health sciences journal, 1997, 16(4):387-93.

6. Molloy AM et al. Folate status and neural tube defects. Biofactors, 1999, 10(2-3):291-4.

7. Barkai G et al. Frequency of Down's syndrome and neural-tube defects in the same family. Lancet, 2003, 361:1331-5.
8. Molloy AM. Folate bioavailability and health. International journal for vitamin and nutrition research, 2002, 72(1):46-52.

9. Vollset SE, Lande B. Knowledge and attitudes of folate and use of dietary supplements among women of reproductive age in Norway 1998. Acta obstetricia et gynecologica scandinavica, 2000, 79(6):513-9.

10. Knowledge and use of folic acid by women of childbearing age-United States, 1995 and 1998. Morbidity and mortality weekly report, 1999, 48(16):325-7.

11. Szumska A et al. Knowledge, attitude and behavior concerning folic acid among women in child bearing age. Frontiers in fetal health, 2000, 2(9-11):1-76.

12. Butterworth CE, Bendich A. Folic acid and prevention of birth defects. Annual review of nutrition, 1996, 16:73-7.

13. Periconceptional folic acid supplementation in Malta. Half-yearly report, July-December, 1999. Valletta, Malta Congenital Anomalies Register, 1999 (http://www.sahha.gov.mt/showdoc.asp $x ?$ id=43\&filesource $=4 \&$ file=hyjuly-dec1999. pdf, accessed 20 January 2010). 